\title{
Development of an Integrated GIS for Monitoring of Anthropogenic Impact on the Coastal Area of Lake Baikal
}

\author{
Andrey S. Gachenko*, Alexey E. Hmelnov, \\ Roman K. Fedorov and Evgeniy S. Fereferov \\ Matrosov Institute for System Dynamics and Control Theory of SB RAS \\ 134 Lermontov Str., Irkutsk, 664033, Russia
}

Received 30.01.2018, received in revised form 22.03.2018, accepted 08.09.2018

Investigation into the causes of the ecological crisis is possible as a result of multicenter studies of the coast and off-shore strip. The development of unified technical and methodological approaches in the assessment of the impact of contaminated subterranean water on the ecosystem is the basis for complex geological-geophysical, geological, geochemical, hydrochemical, hydrological, hydro biological, microbiological, landscape, diving and other researches.

Complex study management involves processing of large amounts of distributed data accumulated during the studies, and needs for their integration and analysis, require the use of modern methods, use of information technology (IT) and tools to support scientific research. Since the studies are interdisciplinary and require the prompt presentation of materials from a large number of scientists from different fields of knowledge, such a system must be multiple-user. Because of the spatial nature of the data, geoinformation systems (GIS) are a suitable tool for the research support on the anthropogenic impact on the ecology of any territory. The implementation of such GIS with open architecture will provide the opportunity to expand functionality by adding new services that are both locally on the geoportal server and remotely on other servers.

System development for assessing and monitoring of human impact as a geoportal has a number of advantages:

- High reliability of data storage;

- Absence of user needs to install and maintain software on his own;

- Free access to methods, models and algorithms of data geoprocessing, the possibility of the list of geo-algorithms expanding;

- The ability to apply high-performance computing to resource-intensive geoprocessing applications.

In this article, an approach for informational support of human impact on the ecology of the coastal zone of Lake Baikal research is suggested. The geoportal of the Irkutsk Scientific Center allows for investigators to make a general database of issue-related data (tabulated data) and map data (information layers), as well as to start-up Internet services for geoprocessing and for complex analysis of various indicators. One of the key features of the geoportal is the ability for users to independently create the structure of their databases (add, delete and modify the structure of tables), and also to adjust start-up of geoprocessing services. This platform allows to take on projects on a variety of topics for a large number of users simultaneously.

(C) Siberian Federal University. All rights reserved

This work is licensed under a Creative Commons Attribution-NonCommercial 4.0 International License (CC BY-NC 4.0).

* Corresponding author E-mail address: gachenko@icc.ru, hmelnov@icc.ru, fedorov@icc.ru, fereferov@icc.ru 
Keywords: ecological crisis, anthropogenic pollution, subakvalny zones of unloading, shallow-water zone, Baikal sponges, subject DB, GIS, geoportal, relief.

Citation: Gachenko A.S., Hmelnov A.E., Fedorov R.K., Fereferov E.S. Development of an integrated GIS for monitoring of anthropogenic impact on the coastal area of lake Baikal, J. Sib. Fed. Univ. Eng. technol., 2018, 11(8), 946-955. DOI: 10.17516/1999494X-0116.

\title{
Разработка комплексной геоинформационной системы мониторинга антропогенного воздействия на прибрежную зону озера Байкал
}

\author{
А.С. Гаченко, А.Е. Хмельнов, Р.К. Федоров, Е.С. Фереферов \\ Институт динамики систем и теории управления \\ имени В.М. Матросова СО РАН \\ Россия, 664033, Иркутск, ул. Лермонтова, 134, а/я 292
}

Установлениепричинэкологического кризисавозможноврезультатекомплексныхисследований побережья и прибрежной акватории. Разработка единых методических и методологических подходов в оиенке воздействия загрязненных подземных вод на экосистему является основой комплексных геолого-геофизических, геологических, геохимических, гидрохимических, гидрологических, гидробиологических, микробиологических, ландшафтных, водолазных и других исследований.

Проведение комплексных исследований сопряжено с обработкой больших объемов накопленных в рамках исследований распределенных данных, необходимостью их комплексирования, анализа и требует применения современных методов, использования информационных технологий (ИТ) и инструментальных средств для поддержки научных исследований. Поскольку исследования имеют междисииплинарный характер и нуждаются в оперативном представлении материалов большого количества ученых из разных областей знаний, такая система должна быть многопользовательской. Из-за пространственного характера данных подходящим инструментом поддержки исследований антропогенного воздействия на экологию какойлибо территории являются геоинформационные системы (ГИС). Реализация такой ГИС с открытой архитектурой обеспечит возможность расширения функциональности за счет добавления новых сервисов, находящихся как локально на сервере геопортала, так и удаленно на других серверах.

Разработка системы для оценки имониторинга антропогенного воздействия в видегеопортала имеет ряд преимуществ:

- высокая надежность хранения данных;

- отсутствие потребности пользователям самостоятельно устанавливать и обслуживать программное обеспечение;

- свободный доступ к методам, моделям и алгоритмам геообработки данных, возможность расширения перечня геоалгоритмов;

- возможность применять для ресурсоемких приложений геообработки системы высокопроизводительных вычислений.

В данной статье предложен подход по информационной поддержке исследований антропогенного воздействия на экологию прибрежной зоны озера Байкал. Геопортал Иркутского научного центра позволяетисследователям формировать общую базутематических данных (табличные данные) и картографических данных (информационные слои), а также осуществлять запуск 
интернет-сервисов для решения задач геообработки и комплексного анализа различных показателей. Одной из отличительных особенностей геопортала является возможность пользователям самостоятельно создавать структуру своих баз данных (добавлять, удалять и модифицировать структуру таблии), а также настраивать запуск сервисов геообработки. Данная платформа позволяет вести проекты по тематике различной направленностии большому количеству пользователей одновременно.

Ключевые слова: экологический кризис, антропогенное загрязнение, субаквальные зоны разгрузки, тематические БД, ГИС, геопортал, рельеф.

\section{Introduction}

Currently the shore of Lake Baikal becomes more and more attractive place for development of tourist activities, and moreover it remains one of the most relevant places with relation to ecological demands and restrictions as it concerns a unique natural object \% Lake Baikal.

A serious impendence of ecological safety of Lake Baikal is posed by accompanying economic activity, especially in the absence of engineering constructions. It is explained by the fact that on the coast of Lake Baikal there is a large number of the local sections of mass tourism and rest that are characterized by permanently growth of tourist flow that finally leads to deterioration of the unique ecological system of Lake Baikal status for that reason acceptance of urgent measures for the analysis and assessment of the current state and for the forecast of dynamics of geosystems on key sections is required: Listvyanka village, Maloye sea cost, coastal area near Severobaikalsk and Baikalsk. The situation thickens by the fact that at the moment groundwater runoff from industrial enterprises, tourism objects, private farms and accommodation units to a surface watercourse is not regulated by any normative documents and thus there is no united methodological approaches to keep records of the factor influence on ecological system of a surface water body.

The lack of methodological approaches the most clearly has appeared on Baikal where a largescale ecological crisis began to take off in 2011 (mainly due to a sharp increase in the tourist flow) which resulted the following events occurred in the coastal zone of the lake:

- mashrooming of filamentous green algae of the Spirogyra kind, atypical for the lake Baikal;

- accumulation of the mass of dead algae and the formation of algobacterial tufts;

- nearly total death of endemic Baikal sponges in the coastal zone of the water area at depths of 3 to $30 \mathrm{~m}$;

- cyanobacteria develop on dead sponges and near them including number of excreting ekssitoksin.

In this context Listvyanka village is considered as a typical example of a settlement located on the shore of the lake Baikal where tourism is widely developing and which was determined as an object of study on identification of the true causes of eutrophication of the coastal zone. In the village of Listvyanka there are many private houses and hotels of various sizes whose sanitary wastewater is not provided with sewage system and enters septic tanks (often not hermetical), where from liquid fecal matter as well as sewage resulting from the use of showers and bath houses, laundering with washing powders, containing a significant amount of phosphorus, pass to Baikal. And while the cause of the ecological crisis of Lake Baikal has not yet been clearly identified it is expected that it can be entry of large amounts of nutrients into the lake \% nitrogen and phosphorus compounds, causing the 
eutrophication of shallow water. Therefore it is supposed to establish a direct connection between the arrival of untreated sewage in the shallows of Lake Baikal and the development of filamentous algae and the sponges death.

At the moment the problem of scientific geoinformation environmental monitoring system creating which is at the initial stage of its formation is being solved. Academic and operating geoinformation presentation of materials to ensure the solution of problems of ecologically sustainable development of territories based on new geoinformation methods and technologies, has become a capstone of scientists' activities, and the task is to develop new hydrophysical methods of searching and adequate determining of the locations of subsoil unloading in assessing the impact on the lake Baikal.

\section{Geoportal of Irkutsk Scientific Center Siberian Branch of the Russian Academy of Sciences}

The main component of the developed service-oriented IAS (information and analytical system) is a geoportal that provides users with the exchange of spatial and thematic data and services for their processing based on OGC standards (Fig. 1). As defined the geoportal is a general access point to information resources (data) and processing technologies.

Software design of the geoportal "client-server" consists of the following components:

- Content management system Calipso \% implements user management functions, webpage slicing, etc.;

- Data base PostgreSQL (with extension for spatial data processing PostGIS) \% is intended for user data storage;

- Data storage system (SCD) \% software and hardware for user data storing;

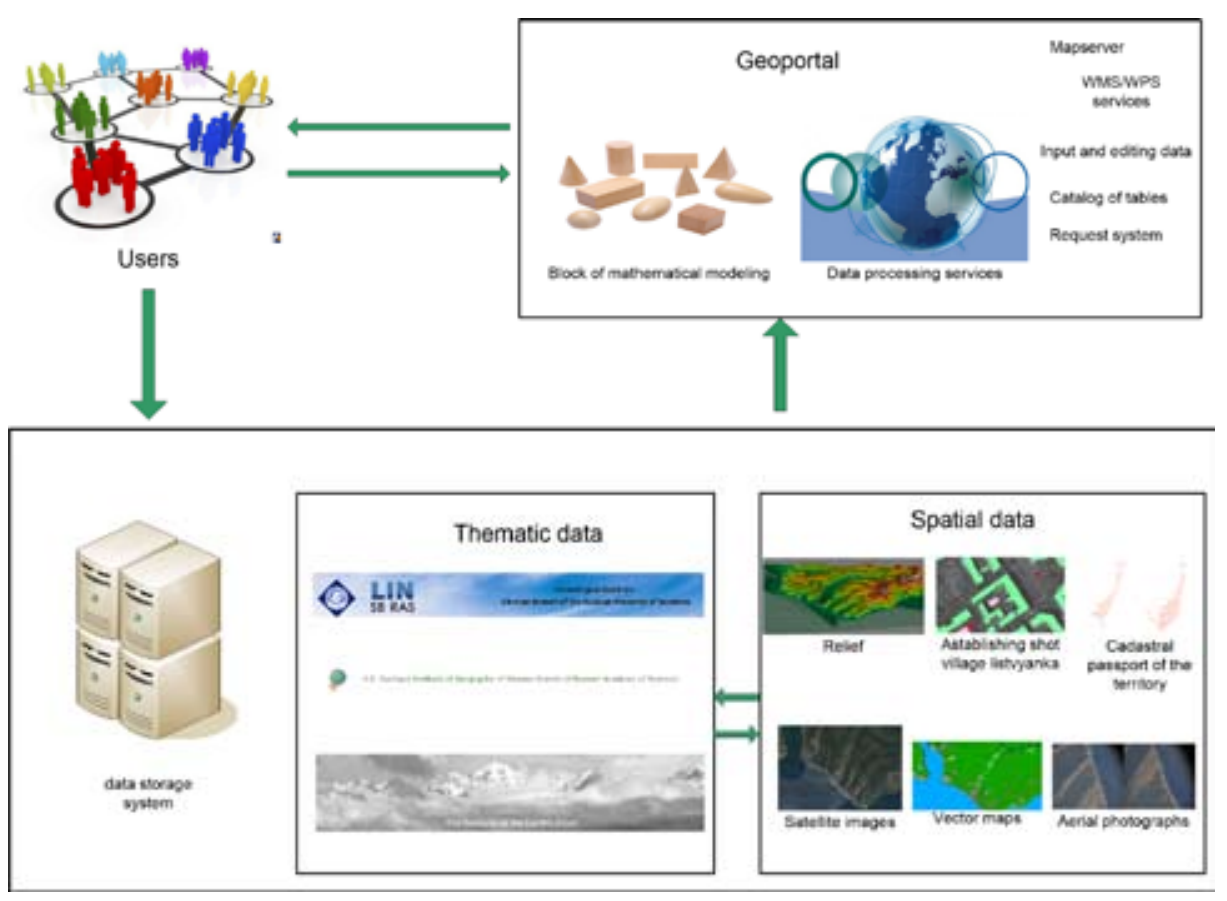

Fig. 1. Software design of GIS of anthropogenic development 
- Services for input and editing of relational data $\%$ allow users to create their own tables with spatial attributes, view and edit tabular data, maps;

- Subsystem of start and status accounting of the execution of WPS services \% manages WPS services;

- WPS-services \% contain algorithms for data processing and analysis, it can be located locally and remotely on the Internet.

\section{Interface of tables input and editing}

The interface for tables input and editing is formed on the basis of structural specifications that contain information about the table, attributes and their properties. Data input and editing is carried out in a table or on a form. The user interface generation module sequentially bypasses all the attributes indicated in the specification. The corresponding control element for each attribute is used to generate input fields on the form and in the table cell. Along with that spatial attributes additionally create WMS layers to display data on the map. You can sort and filter the data in the created table by all attributes.

The use of control elements allows users to create a flexible interface without programming to work with relational tables with any set of attributes. Currently more than twenty different control elements have been developed that permit you to work with standard data types: number, string, date, boolean, etc.

\section{Data mapping}

Table data representation on server side is performed using Mapserver under WMS standard and on the client side using the leaflet library. Mapserver performs data mapping using a special configuration file (MAP) which describes data access settings, used projections, data display styles and so on. The MAP file keeps a request to PostgreSQL to retrieve data from the tables of the basic spatial data and the user table. A new MAP file with a unique name is dynamically created for each layer of the browser's window containing the map. This allows users to simultaneously view the layer with different filters settings and display styles (Fig. 2). Change of filters or display styles will automatically change the configuration file.

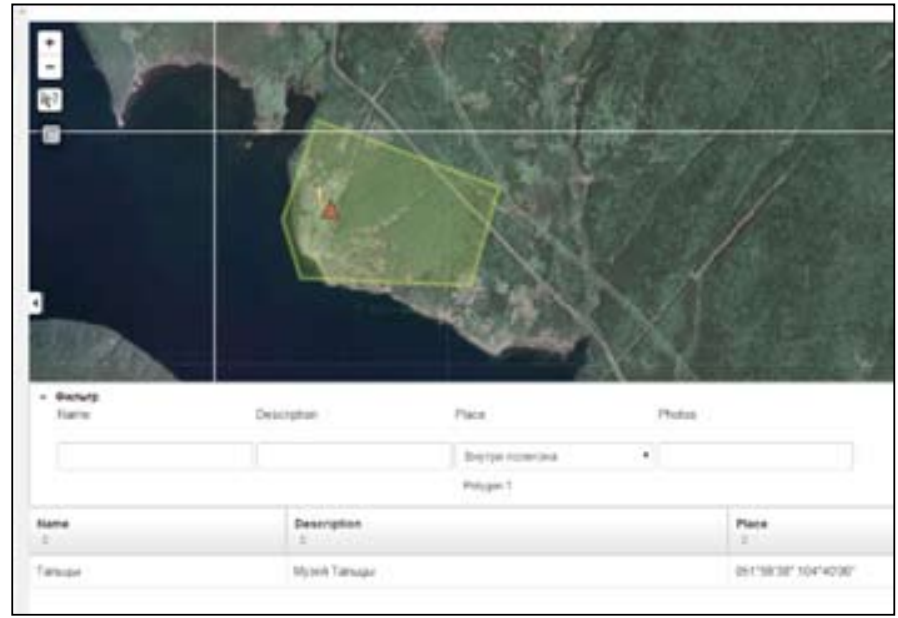

Fig. 2. Data mapping and application of spatial filter 


\section{Generalization and aggregation of tabular data}

A mechanism of data grouping is implemented to aggregate information in the services of input and editing of relational data. Within the interface you can select the fields for grouping the table entries the remaining fields require you to select a group function. For line-oriented fields you can select a group function to count the number of entries in a group. For number fields you can choose one of the following functions: maximum, minimum, average values, quantity. The entries grouping can be made for all types of fields by values equatation.

\section{Performed works}

At the moment, the following materials have been obtained based on the work results on the basis of which it is possible to analyze existing environmental situation and to make the following conclusions:

Digital topographic base for the experimental territory (Listvyanka) on a scale of 1:25000. On the basis of the digital topographic base a 3D model (Fig. 3) of the area was made using proprietary software developed at ISBCT SB RAS.

For a digital map construction of the objects of property location on the territory of Listvyanka village which are potential sources of pollution by sewage. The territory cadastral certificate (CPT) has been obtained from the Public Cadastral Plan of the territory (Fig. 4) for the owned plots (initial data are obtained in the $\mathrm{xml}$ format.)

To make a digital terrain model for the territory of Listvyanka village images of the topographic survey radar \% SRTM (Shuttle Radar Topographic Mission) were obtained.

Satellite images of the investigated territory were obtained for complex territory analysis:

- Satellite images of Listvyanka village of 2006 year. Ground sample Distance is $0.6 \mathrm{~m}$ (provided by Geographical Institute of SB RAS);

- Aerial photographs (Fig. 5) of Listvyanka, September 2014 (provided by Geographical Institute of SB RAS).

- Satellite images of Listvyanka village territory from geoinformation system Google Maps (Fig. 5).

A digital map was made on the basis of the data obtained from the Public cadastral map (Fig. 4) \% the thematic layer "Owned Plots" (Sources of potential pollution by sewage).

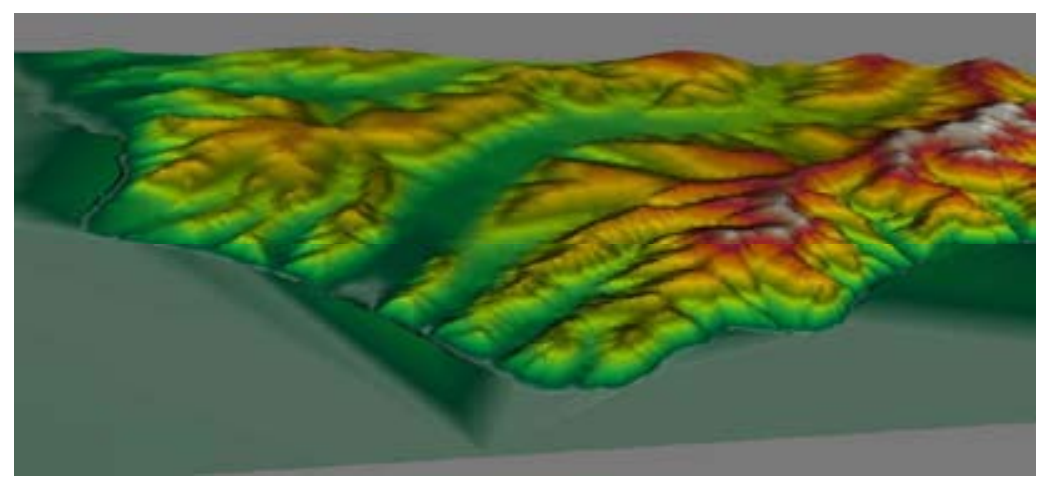

Fig. 3. 3D model of Listvyanka village 
Fig. 4. Cadastral certificate of the territory of Listvyanka village

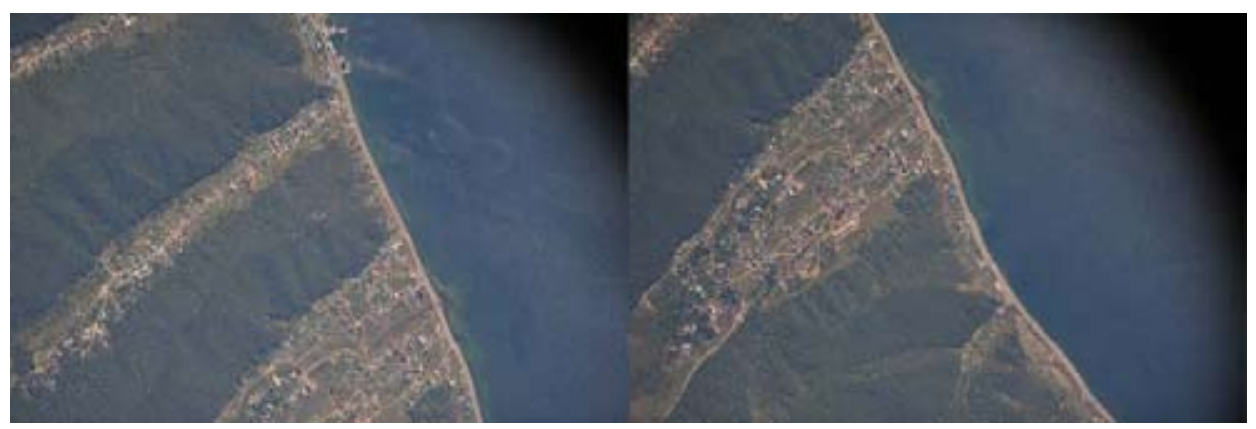

Fig. 5. Aerial photographs of Listvyanka village. September 2014

Based on SRTM data a digital ground local topography of the place is built.

Based on the data obtained by Geographical Institute of SB RAS a DB on potential sources of anthropogenic pollution was created. The database contains information on samples of snow, soil and water taken in 52 locations of the territory and surrounded areas of Listvyanka in different periods. There are quantitative indicators for 11 pollutants for each sample in the database. The collected data allow to obtain integral indicators that carry information on anthropogenic impact on the natural environment for a certain period of time.

For visual representation and modeling on the basis of indicators from the database on potential sources of anthropogenic pollution the corresponding thematic layers were constructed on the geoportal of ISBCT SB RAS.

To assess the contribution of commercial entities to the formation of household pollutants they created a hotel DB (Fig. 6) located on the territory of Listvyanka. In the DB there is information about its capacity (number of rooms), about the availability of its own kitchens and laundries, as well as spatial reference. The work on bounding and display of hotel complexes in satellite image has been carried out. The number of these hotels is constantly growing. Officially, only two of them have authorization documents!

They collected meteorological data of the investigated area and the mechanism for the data displaying was implemented on the geoportal of the ISBCT SB RAS. 


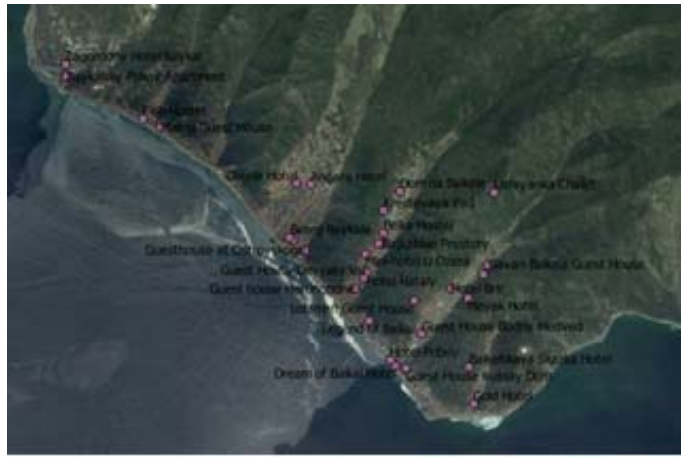

Fig. 6. Hotel complexes in Listvyanka

In 2016-2017 the following complex studies of the coastal area of Listvyanka village were carried out:

- geophysical investigations with simultaneous development of a geophysical explorations methodology relating to the coastal zone of the reservoir by the method of linear electro tomography and by the method of hydrological survey under developed in 2015 method for this project with the use of CTD probe SBE37 37-SM MicroCAT;

- analytical assessment of surface and groundwater impact on the ecological state of the surrounding shallow water zone of Baikal in Listvyanka area;

- diving inspection of Listvyanka water area for evaluation of underwater zones that are mostly subjected to human impact and for development determination of uncharacteristic aquatic vegetation on subaqueous slopes;

- measurement of the elementary composition of the rivers water, intersticial and underground waters of the coastal zone of the lake and its coastal water area in the vicinity of Listvyanka;

- works on chemical microbiological contamination of surface and near-bottom waters determination near Listvyanka village;

- works on determination of chemical contamination of the surface of the territory near Listvyanka according to snow survey data;

- works on the assessment of the modern landscape condition of Listvyanka territory, of the forests health and vegetation in its surroundings for the possible determination of the impact of these territories on the coastal part of Lake Baikal;

- study of underground waters in Krestovaya valley according to the impact of underground run-off of flows from this territory to Lake Baikal with the raw data on sites, potential sources of anthropogenic pollution;

- survey of the village territory with the help of quadrotor helicopter PHANTOM 3 purchased for realization of the project (Fig. 7), including the determination of watercourses influence of the village of Listvyanka and surface runoff to the coastal water area of Lake Baikal and also concerning revealing objects, potential sources of anthropogenic pollution of groundwaters;

- an original technology of a combined digital model construction of a surface and underwater relief based on images of radar topographic survey and bathymetry data was developed; 


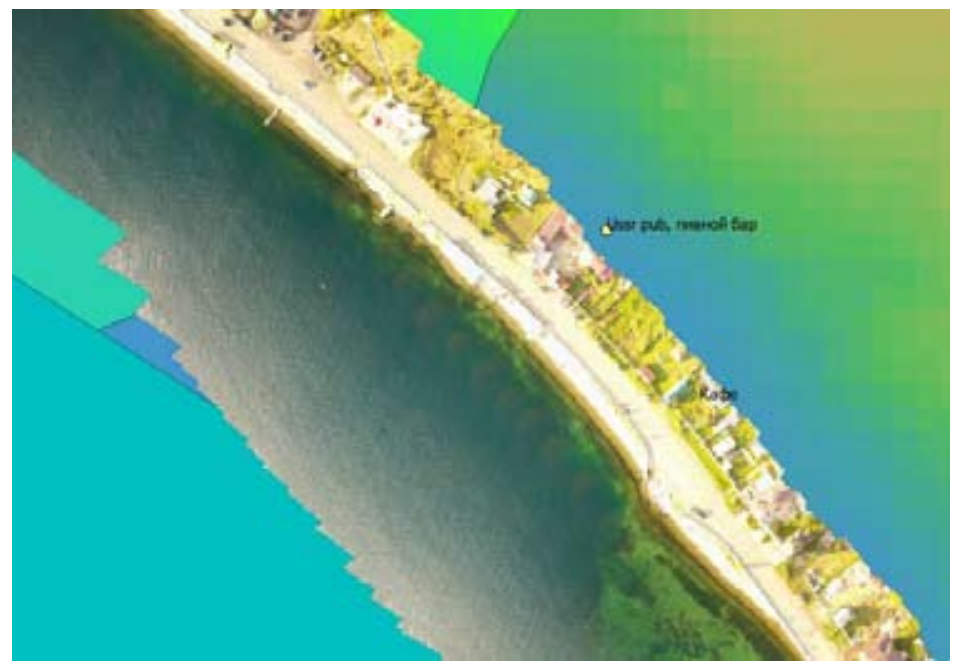

Fig. 7. Survey data from quadrotor helicopter PHANTOM 3 of coastal territory of Listvyanka village

- they implemented a library that provides the construction of triangulation on the basis of altitude and they engineered bathymetry data and software for morphing electronic maps which provides adjustment and combination of models of underwater and above-water reliefs in conditions of inadequate data.

All received data are placed on the geoportal of ISBCT SB RAS. This allows to carry out a complex analysis of a large volumes of data.

The obtained results of integrated studies on investigation of causes of the ecological crisis developing near lake Baikal (of coast and coastal waters and the territory of Listvyanka itself), for development of united methodic and methodological approaches to the detection of anthropogenically polluted groundwater with subaqueous empting in the reservoir give definite basis for the conclusion about causal relationship between the increase in the volume of underground runoff of anthropogenically polluted waters (having subaqual unloading in the littoral part of Lake Baikal) with the development of the ecological crisis recorded in the reservoir. At the same time the main and determinative factors for its development are still being established. Based on the results of the performed works it can be said that currently the most probable causes of the crisis are:

- microbiological contamination;

- chemical pollution;

- thermal pollution.

The first and major result of work is microbiological pollution.

\section{Conclusion}

The article offers infrastructural approach of information and analytical systems creation for managing large-scale emergent interdisciplinary projects based on the use of a service-oriented paradigm, OGC standards, Web technologies and services. As a result of the performed works they developed an architecture and created GIS monitoring to support investigation on anthropogenic impact on the ecology of the coastal zone of Lake Baikal. The system provides for all researchers a 
centralized formation of thematic and cartographic databases results of thy research, monitoring of the ecological situation, a complex analysis of human intervention impact on the ecology of the coastal zone of Lake Baikal. Open architecture of the developed geoportal allows to expand its functionality by adding new services being locally on the geoportal server and remotely on other servers. They developed structure of the database and the results of the research were entered. The total number of determinants is over 100 .

They carried out analysis of sewage water from the objects of the tourist infrastructure with the help of GIS tools based on the forming of the drainage-basin topography according to the relief and estimation of the number of tourist infrastructure facilities in the zone of each basin.

\section{Acknowledgements}

The presented software is developed using the Shared Computing Center of Integrated Information and Computing Network of Irkutsk Researchand Educational Complex (http://net.icc. $\mathrm{ru}$. The study was partially financially supported as part of integration project 4.1: "Development of unified methodological approaches in determining of anthropogenicimpact on the surface water in the area of subaqueous discharge of contaminated sewage of soil water (using as example the area of Listvyanka village).

\section{References}

[1] Фереферов Е.С., Минаев В.В., Михайлов А.А., Гаченко А.С., Власова Н.В., Воробьева Н.В., Федоров Р.К., Хмельнов А.Е. Информационно-аналитическая система мониторинга и оценки антропогенного воздействия на экологию прибрежной зоны озера Байкал. География $u$ природные ресурсы. 2016, 6, 174-178. [Fereferov E.S., Minaev V.V., Mikhailov A.A., Gachenko A.S., Vlasova N.V., Vorobyeva I.B., Fedorov R.K., Hmelnov A.E. Information-analytical system for monitoring and assessment of anthropogenic impacts on the ecology of the coastal area of lake Baikal. Geography and natural resources, 2016, (6), 174-178. (in Russian)]

[2] Бычков И.В., Ружников Г.М., Хмельнов А.Е., Фёдоров Р.К., Парамонов В.В., Шигаров А.О., Фереферов Е.С., Гаченко А.С., Михайлов А.А., Маджара Т.И., Шумилов А.С., Авраменко Ю.В. Инфраструктура информационных ресурсов и технологии создания информационноаналитических систем территориального управления, Новосибирск, Издательство СО РАН, 2016. 242 c. [Bychkov I.V., Rugnikov G.M., Hmelnov A.E., Fedorov R.K., Paramonov V.V., Shigarov A.O., Fereferov E.S., Gachenko A.S., Mihailov A.A., Madzhara T.I., Shumilov A.S., Avramenko Yu.V. Infrastructure of information resources and technologies and of information and analytical systems of territorial management creation. Novosibirsk, Publishing house SB RAS, 2016, 242. (in Russian)]

[3] Хмельнов А.Е., Гаченко А.С. Реализация совмещения неточной модели рельефа речного дна с моделью надводного рельефа. Вестник БГУ. Математика, информатика, 2016. 2, 77-84. [Hmelnov A.E., Gachenko A.S. Achievement of inaccurate river underwater topography model combination with above-water relief model. Bulletin of the Buryat State University. Mathematics, Informatics, 2016, 2, 77-84. (in Russian)]

[4] Fereferov E.S., Bychkov I.V., Gachenko A.S., Rugnikov G.M., Hmelnov A.E. Methods for Automation of Development of Information Systems Using Specifications of Database Applications. International Conference "Mathematical and Information Technologies" (MIT-2016), 2016, 141-142. 